\title{
Comparison of double-phase impression technique in 1 step and 2 steps by evaluating dimensional stability and accuracy of condensation silicones
}

\author{
Borjan Naumovski ${ }^{1}$, Jadranka Bundevska ${ }^{1}$, Biljana Kapusevska ${ }^{1}$ \\ ${ }^{1}$ University Dental Clinical Center, Dental Faculty, Ss. Cyril and Methodius University, \\ Majka Tereza 17, 1000 Skopje, Republic of Macedonia
}

Received: January 2018; Accepted: February 2018

\begin{abstract}
The diverse viscosities of silicone impression materials are suited for their use in various impression techniques, intended to improve the precision of the cast impression in the form of a plaster model. The purpose of this research is to determine the dimensional stability and accuracy of the double-phase impression technique in 1 step and 2 steps by using a condensation silicone impression material. This research was carried out by using a precise stainless-steel master model and an individual aluminum tray. Comparing the abutments of the master model and the abutments of the double-phase impression technique in 2 steps, showed that they are wider on average $81 \mu \mathrm{m}$, while the abutments from the double-phase impression technique in 1 step are on average $281 \mu \mathrm{m}$ wider in diameter. After analyzing the results obtained in relation to the diameter of the abutments, it can be concluded that the double-phase impression technique in 2 steps is dimensionally more stable and accurate compared to the double-phase impression technique in 1 step. This study shows that dimensional stability and accuracy of impression materials also depend on the selection of appropriate impression technique and proper performance in order to obtain a high quality dental impression that will be the basis for an accurate fixed-prosthodontic fabrication.
\end{abstract}

Keywords: silicone impression material, impression technique, fixed partial dentures, dimensional stability and accuracy

\section{Introduction}

Silicone impression materials are most widely used in dentistry for the reproduction of oral cavity structures due to their high accuracy and dimensional stability (Rubel, 2007). According to American Dental Association (ADA) No. 19 and Elastomeric Impression Materials ISO 48232015, the silicone-based materials are divided into 4 types i.e. gradations by their viscosity and consistency: type - 0 , putty consistency (very high viscosity); type - 1, heavy consistency (high viscosity); type - 2, soft consistency (medium viscosity), type - 3, light consistency (low viscosity).The diverse viscosities of silicone impression materials are suited for their use in various impression techniques, intended to improve the precision of the cast impression in the form of a plaster model (Franco et al., 2011).

Condensation silicones belong to the elastomeric group of impression materials and their setting is obtained by cross-linking polycondensation reaction of hydroxyl terminated polysiloxane pre-polymers with tetra alkoxysilanes catalyzed by dibutyl-tin dilaurate (DBTD). The polycondensation process releases alcohol that contributes to the contraction (reduction) of the impression (Islamova et al., 2016). Advantages of condensation silicon are: precise impression if poured quickly after being taken and good elastic restoration after

\footnotetext{
*naumovskiborjan@gmail.com
} 
removing the impression from the mouth. Disadvantages are: hydrophobic, contraction (reduction) of the impression with the lapse of time (up to 4 hours) and possible allergic reaction caused by the catalyst (Chen et al., 2004; Gonçalves et al., 2011).

The process of setting (polymerization) of silicones starts from the very beginning with the mixing i.e. the contact of the basic material and the reactor (activator). The first elastic particles emerge which, over the time, multiply and interconnect, leading to full polymerization of the impression material and its transformation from plastic to elastic condition.

Two stages are differentiated in the process of setting of silicones. The first stage is the hardening of the material which, in clinical terms, enables extraction of the impression from the mouth without any deformation. The second stage comes upon the extraction of the impression and lasts in some materials up to an hour, until the polymerization is fully completed. During that time, certain dimensional changes on the impression material are possible, and, with its completion, the time convenient for casting of the impression begins (Marković et al., 2012).

Although silicones have unconditional dimensional accuracy, Samet et al. (2005) illustrated in a research that nearly $90 \%$ of the cast models have one or more visible errors and therefore require further examination and improvement.

Different impression techniques are vital in transferring an accurate copy of the prepared teeth and the surrounding soft tissue complex for further work. The application of impression materials of different consistencies and their use in multiple steps contributes in recording the finest details of the original (Caputi and Varvara, 2008).

Shah et al. (2004) used a 3D laser scanner and compatible software to scan and measure the plaster models obtained with the 1 step, double-phase impression technique in examining the accuracy of various elastomeric impression materials. This paper emphasizes the use of 3D scanner and adequate software as a new method for evaluation and analysis of the dimensional stability and accuracy of the impression materials and techniques by digital measurement and comparison of the cast plaster models.

The purpose of this research is to determine the dimensional stability and accuracy of double-phase impression technique in 1 step and 2 steps and comparison of dimensional stability and accuracy of the double-phase impression technique in 1 step with the double-phase impression technique in 2 steps by using a condensation silicone impression material.

\section{Material and methods}

This research was carried out by using a precise stainless-steel master model. This master model was produced by milling a block of stainless steel in a CNC machine, according to an originally drawn 3D model in AutoCAD, which is in accordance with the ISO 12836, 2015.

The metal model is composed of two abutments, beveled 6 degrees to the top, laid on a metal base, simulating a 3 unit dental bridge preparation for two connectors and pontic. The distance between the centers of the abutments is $30 \mathrm{~mm}$, the diameter is $5 \mathrm{~mm}$, and their height is $10 \mathrm{~mm}$. There are 4 metal wedges on the metal base, 2 on both sides respectively, as an orientation for exact and identical setting of the tray at each impression. There are also outflow grooves on the metal base for the flow of the excess of impression material during the process. It was used as ultimate standard (control) model based on which all the impressions in this research were made.

For the needs of this research, an individual aluminum tray was made, on the same basis as the master model, appropriately perforated for a better retention of the impression material with the tray. The individual tray was specifically designed to cover the entire model, with $7 \mathrm{~mm}$ space between the abutments and the inner wall, with 4 holes appropriately positioned on the metal wedges on the metal base for accurate orientation so that it can intimately fit in on the metal base for complete impression.

All impressions were left to the master model twice as long as the required setting time (Sayed et al., 2016) to compensate for the polymerization time that takes place at room temperature $\left(\sim 25{ }^{\circ} \mathrm{C}\right)$ and not at oral cavity temperature $\left(\sim 32{ }^{\circ} \mathrm{C}\right)$ (ISO 4823-2015). Special attention was paid to the contact between the model and the tray as a confirmation of the complete placement of the individual tray on the base of the model. Contact between the master model and the tray is achieved by pressing the fingers over the tray, simulating ambulance work.

In this research, 2 impression techniques were performed, the double-phase technique in 1 step and the double-phase technique in 2 steps using condensation silicone with different consistency.

\section{Double-phase impression technique in 1 step}

Aptly amount of heavy body silicone and catalyst are mixed and then placed in the tray while the light body silicone mixed with a catalyst is applied around the abutments placed on the metal model. After applying the light body silicone, the individual tray with the heavy body silicone is placed over the abutments, up to the metal-to-metal contact. After an interval twice longer than the time prescribed by the manufacturer for siliconpolymer binding, the tray is separated from the model by a manipulation exactly the same as when working with a patient. 


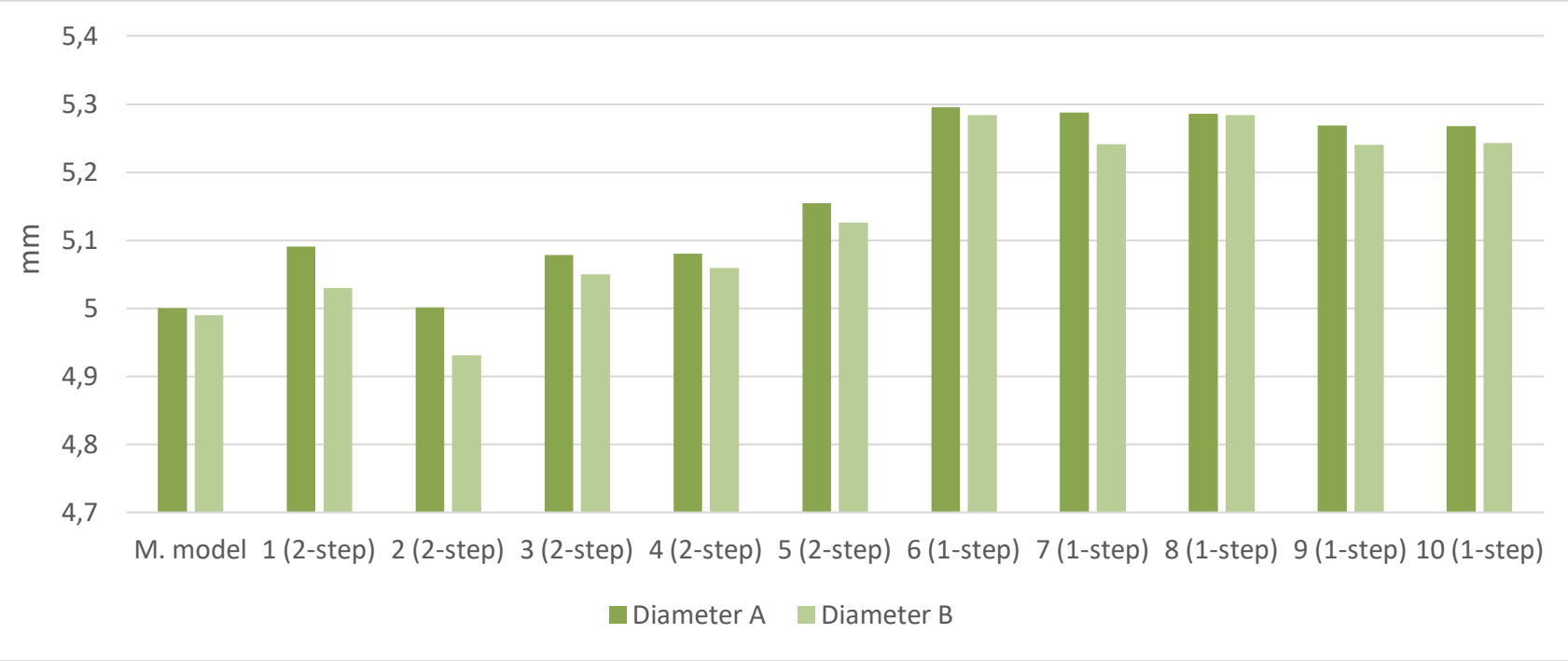

Fig. 1 Diameter (mm) of abutments A and B.

\section{Double-phase impression technique in 2 steps}

Aptly amount of heavy body silicone and catalyst are mixed and then placed in the tray. A first impressions from the metal abutments is taken with the heavy body silicone.

After hardening of the mass, the tray is removed from the model, and by means of a scalpel, outflow channels for evacuation of the excess light body silicone in the second impression phase are made. The impression is dried to remove humidity. A light body silicone is mixed with a catalyst and placed into the first impression of the metal abutments. The prepared impression is then returned to the metal model for re-printing, up to the metal-to-metal contact. After an interval twice longer than the time prescribed by the manufacturer for siliconpolymer binding, the tray is separated from the model by a manipulation, exactly the same as when working with a patient.

The materials used in this research are condensation silicon type 0 (Optosil Comfort Putty, Heraeus, Germany) and condensation silicone type 3 (Xantopren L Blue, Heraeus, Germany).

The impressions were poured with super hard stone (Moldasynt, Heraeus, Germany) and after the hardening, the plaster model was separated from the mold after 1 hour. The cast plaster models were scanned with a 3shape 3D laser scanner and were transferred in *.stl format to an appropriate software program (3D builder) where the examined dimensions were precisely measured. To avoid statistical errors, the measurements were performed three times and a mean values were obtained (Dugal et al., 2013).

To assess dimensional stability and accuracy, subject of measurement of this model was: 1). the distance between the two abutments and 2). the diameter of the tip of the abutments.

\section{Results}

The results of the 10 impressions are shown in Figure 1 . Models 1 to 5 were taken with the doublephase impression technique in 2 steps whereas models 6 to 10 were taken with the double-phase impression technique in 1 step. The difference between the two impression techniques is clearly visible i.e. the diameter of the abutments taken with the double-phase impression technique in 1 step are on average $200 \mu \mathrm{m}$ wider compared to the diameter of the abutments taken with the double-phase impression technique in 2 steps. Comparing the abutments of the master model and the abutments of the double-phase impression technique in 2 steps, showed that they are wider on average $81 \mu \mathrm{m}$, while the abutments from the double-phase impression technique in 1 step are on average $281 \mu \mathrm{m}$ wider in diameter.

The results in Figure 2, which refer to the distances between the abutments taken with both impression techniques, show that there is a negative deviation in relation to the master model in both impression techniques on average $51 \mu \mathrm{m}$ in the double-phase impression technique in 2 steps and $56 \mu \mathrm{m}$ in the double-phase impression technique in 1 step. Comparing the distances between the abutments in these two impression techniques, no statistically significant differences between the double-phase impression technique in 2 steps and the double-phase impression technique in 1 step were noticed. 


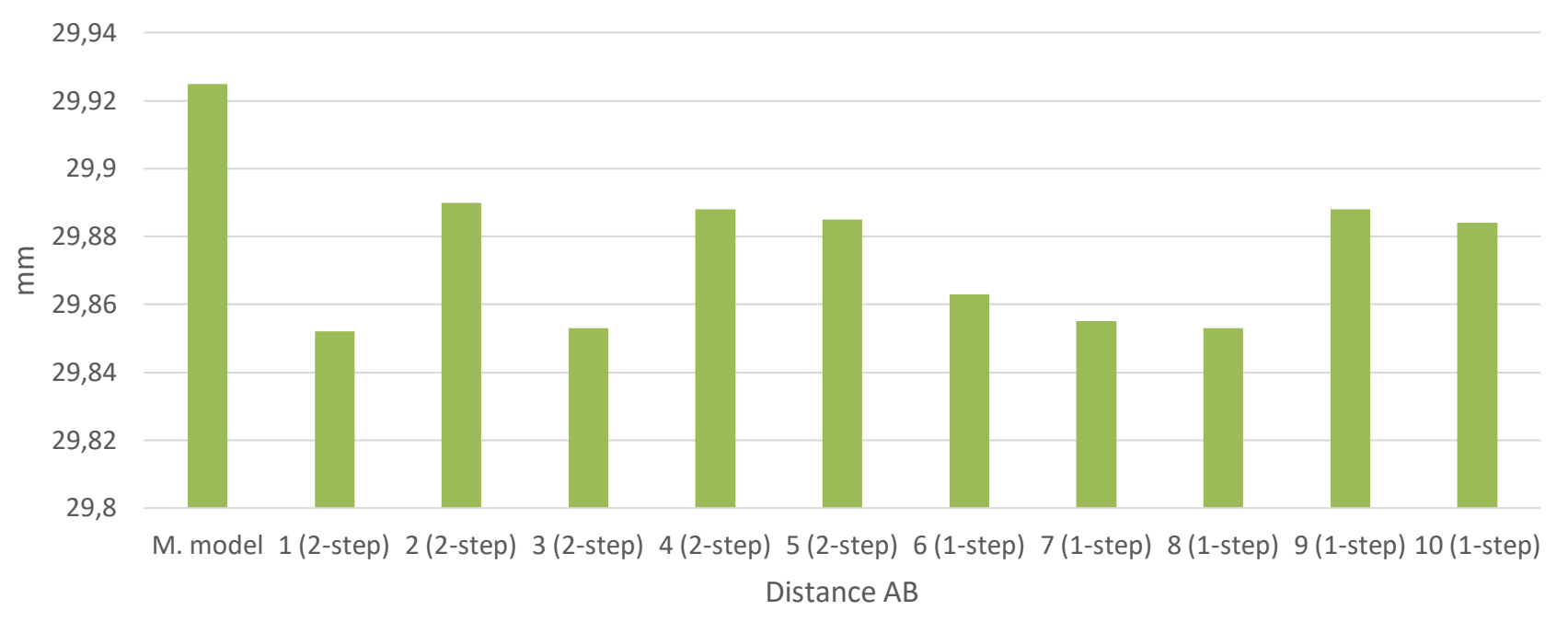

Fig. 2 Distance (mm) between abutments A and B.

\section{Discussion}

Currently, there are numerous opposing views in the scientific literature regarding the dimensional stability and accuracy of the impression techniques. Analysis of the advantages and disadvantages of various impression techniques was an incentive for this research. The scientific knowledge in the literature outlines the advantages of the double-phase impression technique in 1 step (Faria et al., 2008; Hung et al., 1992; Pande and Parkhedkar, 2013), while the research results of other authors favor the double-phase impression technique in 2 steps (Chugh et al., 2012; Leão et al., 2014; Nissan et al., 2002; Silva et al., 2016; Singh et al., 2012). The main advantage of the double-phase impression technique in 1 step is in the significantly shorter execution time, the lesser trauma of the patient i.e. taking of the impression in one step (stage). The main argument in favor of the double-phase impression technique in 2 steps is the ability to control the amount of light body silicone applied in the second step of the imprinting. This provides the possibility of making outflow channels from the imprinted abutments to allow flow of the excess light body silicone after taking the impression with the heavy body silicone. The double-phase impression technique in 2 steps has a relatively controlled space between the abutment and the silicone impression material with very high viscosity and allows control of the amount of low viscosity silicone applied, which significantly increases the accuracy of this technique (Nissan et al., 2002).

The dimensional changes of the impression depend on the possibility for elastic recovery of the silicone after its removal from the model by manipulative movements used in everyday clinical practice, as well as the changes occurring in the impression material after its casting at several intervals and multiple casts (Rathee et al., 2014).
Particular control of the amount of impression material is needed, because a large amount of impression mass does not mean a good impression. Quite the opposite, better results are obtained when the impression layer is of moderate thickness and even distribution of the impression mass. It implies application or use of strictly controlled space providers with clear thickness or an individual tray. The elastomer with even layer provides a good coating of the impression surface; it penetrates into the underlying spaces and, after the completion of the polymerization, it is well bound to the tray (Mubashir et al., 2015; Nagwa et al., 2015).

It is advisable that the impression material is under certain, slight pressure at the moment of placement on the impression surface. Such pressure is required for a proper surface coating with the impression mass, allowing penetration of elastomer into the underlying spaces and thus eliminating trapped air and fluids. In terms of time and intensity, a controlled pressure can only be provided with an individual tray (Leão et al., 2014).

During the 1 step, double-phase impressions, after separating the individual tray from the master model, it was noticed that the impressions of the abutments were unevenly covered by the two types of silicone. Half of the imprinted abutment, or more precisely from the middle to the abutment base, was fully imprinted with the light body silicone while the other (upper) half was completely imprinted with the heavy body silicone. This impression profile is a result of the suppression and extrusion of the light body silicone by the heavy body towards the abutment base because of its density which is superior when these two are used at once. In contrast to the 1-step impression, in the double-phase 2-step impression, the abutment impressions were fully covered with the light body silicone. This is due to the difference in the composition of the light and heavy body silicone, the size 
and density of the polymers, and therefore their accuracy and stability in the imprinting.

The study of Vitti et al. (2013) measures and compares the dimensional accuracy of plaster models cast of two different condensation silicones and two different addition silicones with three impression techniques (mono-phase, double-phase in 1 step and double-phase in 2 steps). The measurements of all examined distances of the plaster models showed distorted dimensions with significant negative linear changes (contraction) in relation to the standard (control) model, cast of stainless steel. The plaster models derived from the examined addition silicones were dimensionally more precise compared to the examined condensation silicones while no difference was observed between the impression techniques. It should be noted that the author minimized the effect of elastic changes when taking the tray out of the standard model, which is not the case in everyday clinical practice.

Singh et al. (2012) estimated the linear dimensional accuracy of the elastomeric impressions by using different impression techniques and various combinations of viscosity of the impression materials. The findings, which are based on the research conditions and results obtained, support the double-phase 2-step impression, whereby he stressed that it requires further research and studies to generalize the accuracy of the double-phase 2step impression of silicones with different viscosity.

Heidari et al. (2016) in their experimental study evaluated the effect of the light body silicone spacer on the precision of the cast models taken with the doublephase technique in 2 steps by applying two different addition silicones. The results point out that the precision of the double-phase technique in 2 steps without the controlled light body silicone spacer is desirable. The effect of the controlled light body silicone spacer of 0.5 $\mathrm{mm}, 1 \mathrm{~mm}, 1.5 \mathrm{~mm}$ and $2 \mathrm{~mm}$ and of the one without spacer in the final dimensional accuracy did not show an important difference.

The diversity of results obtained in the analysis of various impression techniques is best depicted in the study of Faria et al. (2008) who aimed in their research to make a comparison of the accuracy of different impression materials used in the fabrication of fixed partial dentures. For the purpose of this research, a master (steel) model was cast which is a half arch of the partial edentulous mandible, where the teeth are prepared for fixed partial dentures. Differences were noticed between the impression techniques and a conclusion was drawn that the double-phase 1-step impression has a better accuracy than the double-phase 2-step impression. Such results support the findings in the study of Hung et al. (1992), in which there is a comparison between the double-phase technique in 1 step and 2 steps using addition silicones and is thereby confirmed that the double-phase technique in 1 step is more accurate than the double-phase technique in 2 steps.
Nissan et al. (2000) advises in his study the use of the double-phase technique in 2 steps since an accurate impression requires equal spacer so that the low viscosity silicone (light consistency) can be evenly polymerized.

In their study, Chugh et al. (2012) compared the accuracy of plaster models derived from different impression techniques (double-phase technique in 1 step and 2 steps) using several space providers around the abutments and came to a conclusion that the double-phase impression technique in 2 steps with equal and controlled spacer of $0.5 \mathrm{~mm}$ is recommended for obtaining a plaster model for precise fabrication of fixed partial dentures. The clinical application of this study is the use of temporary crowns as a controlled spacer for the light body silicone.

In correlation with this research as regards the obtained results is the study of Haralur et al. (2016), who studied the precision of the cast models after imprinting the master steel model with the double-phase impression technique in 1 step and 2 steps. The results showed that the cast abutments were relatively broader in diameter with the double-phase impression technique in 1 step due to the polymerization contraction to the wall of the tray by the heavy body silicone.

\section{Conclusion}

Silicones are the most widely used impression materials in everyday dental clinical practice for accurate impression of dental morphology and surrounding soft tissue, and, as such, their wide usage in dental practice is justified. This study shows that their dimensional stability and accuracy also depend on the selection of appropriate impression technique and proper performance in order to obtain a high-quality dental impression that will be the basis for an accurate fixed-prosthodontic fabrication.

After analyzing the results obtained in relation to the diameter of the abutments, it can be concluded that the double-phase impression technique in 2 steps is dimensionally more stable and more accurate compared to the double-phase impression technique in 1 step.

The deviations in the values obtained by measuring the distance between the abutments in these two impression techniques in relation to the reference model, point out the need for further research by using a variety of impression techniques and materials.

\section{References}

Caputi, S., Varvara, G., 2008. Dimensional accuracy of resultant casts made by a monophase,one-step and twostep, and a novel two-step putty/light-body impression technique: an in vitro study. J. Prosthet. Dent. 99(4), 274281. Available at: https://doi.org/10.1016/S0022-3913(08)60061-X. 
Chen, S.Y., Liang, W.M., Chen, F.N., 2004. Factors affecting the accuracy of elastometric impression materials. J. Dent. 32(8), 603-609. Available at: https://doi.org/10.1016/j.jdent.2004.04.002.

Chugh, A., Arora, A., Singh, V.P., 2012. Accuracy of different putty-wash impression techniques with various spacer thicknesses. Int. J. Clin. Pediatr. Dent. 5(1), 33-38. Available at: https://doi.org/10.5005/jp-journals-100051131.

Dentistry - Digitizing devices for CAD/CAM systems for indirect dental restorations -- Test methods for assessing accuracy ISO 12836, 2015.

Dentistry - Elastomeric impression materials ISO 4823, 2015.

Dugal, R., Railkar, B., Musani, S., 2013. Comparative evaluation of dimensional accuracy of different polyvinyl siloxane putty-wash impression techniques-in vitro study. J. Int. Oral. Health. 5(5), 85-94.

Faria, A.C., Rodrigues, R.C., Macedo, A.P., MattosMda, G., Ribeiro, R.F., 2008. Accuracy of stone casts obtained by different impression materials. Braz. Oral. Res. 22(4), 293-298. Available at: https://doi.org/10.1590/s180683242008000400002.

Franco, E.B., da Cunha, L.F., Herrera, F.S., Benetti, A.R., 2011. Accuracy of single-step versus 2-step double-mix impression technique. ISRN Dent. 341546. Available at: https://doi.org/10.5402/2011/341546.

Gonçalves, F.S., Popoff, D.A., Castro, C.D., Silva, G.C., Magalhães, C.S., Moreira, A.N., 2011. Dimensional stability of elastomeric impression materials: a critical review of the literature. Eur. J. Prosthodont. Restor. Dent. 19(4), 163-166.

Haralur, S.B., Toman, M.S., Al-Shahrani, A.A., Al-Qarni, A.A., 2016. Accuracy of multiple pour cast from various elastomer impression methods. International Journal of Dentistry (1), 1-6. Available at: https://doi.org/10.1155/2016/7414737.

Heidari, B., Fallahi, S., Izadi, A., Soufiabadi, S., Souri, H., Fotovat, F., 2016. Experimental investigation of effect of light-body material space on the accuracy of casts resulting of two-stage impression technique in two types of additive silicone. I.J.B.P.A.S. 5(9), 3320-3330.

Hung, S.H., Purk, J.H., Tira, D.E., Eick, J.D., 1992. Accuracy of one-step versus two-step putty wash addition silicone impression technique. J. Prosthet. Dent. 67(5), 83-89. Available at: https://doi.org/10.1016/0022-3913(92)90151-y.

Islamova, R.M., Dobrynin, M.V., Ivanov, D.M., Vlasov, A.V., Kaganova, E.V., Grigoryan, G.V., Kukushkin, V.Y., 2016. bis-Nitrile and bis-Dialkylcyanamide platinum(II) complexes as efficient catalysts for hydrosilylation crosslinking of siloxane polymers. Molecules 21(3), 311. Available at: https://doi.org/10.3390/molecules21030311.

Leão, M.P., Pinto, C.P., Sponchiado, A.P., Ornaghi, B.P., 2014. Dimensional stability of a novel polyvinylsiloxane impression technique. Braz. J. Oral. Sci. 13(2), 118-123. Available at: http://dx.doi.org/10.1590/1677-3225v13n2a08

Marković, D., Puškar, T., Hadžistević, M., Potran, M., Blažić, L., Hodolič, J., 2012. The dimensional stability of elastomeric dental impression materials. Contemporary Materials III-1, 105-110. Available at: https://doi.org/10.1016/0022-3913(84)90336-6.

Mubashir, A.S., Motwani, B.K., Sahu, S., Singh, S., Kulkarni,
S., 2015. Dimensional accuracy \& Stability of silicone putty wash impression technique with different thickness of light body material. J. Cont. Med. A. Dent. 3(1), 81-84. Available at: https://doi.org/10.18049/jcmad/319a17.

Nissan, J., Gross, M., Shifman, A., Assif, D., 2002. Effect of wash bulk on the accuracy of polyvinyl siloxane puttywash impressions. J. Oral. Rehabil. 29(4), 357-361. Available at: https://doi.org/10.1046/j.1365-2842.2002.00820.x.

Nissan, J., Laufer, B.Z., Brosh, T., Assif, D., 2000. Accuracy of three polyvinyl siloxane putty-wash impression techniques. J. Prosthet. Dent. 83(2), 161-165. Available at: https://doi.org/10.1016/s0022-3913(00)80007-4.

Pande, N.A., Parkhedkar, R. D., 2013. An evaluation of dimensional accuracy of one-step and two-step impression technique using addition silicone impression material: An in vitro study. J. Indian Prosthodont. Soc. 13(3), 254-259. Available at: https://doi.org/10.1007/s13191-012-0182-1.

Rathee, S., Eswaran, B., Eswaran, M., Prabhu, R., Geetha, K., Krishna, G., Jagadeshwari, A., 2014. Comparison of dimensional accuracy of addition silicone of different consistencies with two Different spacer designs - In-vitro study. J. Clin. Diagn. Res. 8(7), ZC38-41. Available at: https://doi.org/10.7860/JCDR/2014/9139.4585.

Rubel, B.S., 2007. Impression materials: a comparative review of impression materials most commonly used in restorative dentistry. Dent. Clin. North. Am. 51(3), 629642. Available at: https://doi.org/10.1016/j.cden.2007.03.006.

Samet, N., Shohat, M., Livny, A., Weiss, E.I., 2005. A clinical evaluation of fixed partial denture impressions. J. Prosthet. Dent. 94(2), 112-117. Available at: https://doi.org/10.1016/j.prosdent.2005.05.002.

Sayed, M.E., Al-Makramani, B.M., Al-Sanabani, F.A., Mohamed, M.S., 2016. Effect of intermixing brands on the dimensional accuracy of master cast using putty-wash impression technique. J. Contemp. Dent. Pract. 17(9), 734-739. Available at: https://doi.org/10.5005/jp-journals10024-1921.

Sayed, N.M., Aly, N.H., Rayyan, M.M., 2015. The effect of different double- step impression techniques on accuracy of stone dies. E.D.J.61(1), 641-650.

Shah, S., Sundaram, G., Bartlett, D., Sherriff, M., 2004. The use of a 3D laser scanner using super impositional software to assess the accuracy of impression techniques. J. Dent. 32(8), 653-658. Available at: https://doi.org/10.1016/j.jdent.2004.07.005.

Silva, S.C., Messias, A.M., Abi-Rached, FO., de Souza, R.F., Reis, J.M., 2016. Accuracy of gypsum casts after different impression techniques and double pouring. PLoS One 13(10), 164-168. Available at: https://doi.org/10.1371/journal.pone.0164825.

Singh, K., Sahoo, S., Prasad, K.D., Goel, M., Singh, A., 2012. Effect of different impression techniques on the dimensional accuracy of impressions using various elastomeric impression materials: an in vitro study. J. Contemp. Dent. Pract. 13(1), 98-106. Available at: https://doi.org/10.5005/jp-journals-10024-1102.

Vitti, R.P., da Silva, M.A., Consani, R.L., Sinhoreti, M.A., 2013. Dimensional accuracy of stone casts made from silicone-based impression materials and three impression techniques. Braz. Dent. J. 24(5), 498-502. Available at: https://doi.org/10.1590/0103-6440201302334. 


\title{
Резиме
}

\section{Компарација на двофазна отпечаточна техника во 1 чекор и 2 чекора при евалуација на димензионална стабилност и прецизност кај кондензациони силикони}

\author{
Борјан Наумовски ${ }^{*}$ Јадранка Бундевска, Билјана Капушевска \\ Универзитетски стоматолошки клинички центар, Стоматолошки факултет, \\ Универзитет „Св. Кирил и Методиј”, Мајка Тереза 17, 1000 Скопје, \\ Република Македонија
}

Клучни зборови: силиконски отпечаточен материјал, отпечаточна техника, фикснопротетички изработки, димензионална стабилност и прецизност

Силиконските отпечаточни материјали со различната вискозност може да бидат применети кај различни отпечаточни техники и со тоа даваат можност за подобрување на прецизноста на излеаниот отпечаток во гипсен модел. Целта на ова истражување е одредување на димензионалната стабилност и прецизност на двофазна отпечаточна техника во 1 чекор и 2 чекора со употреба на кондензационен силиконски отпечаточен материјал. Во истражувањето користени се прецизен експериментален челичен модел и алуминиумска индивидуална лажица. Споредувајќи ги абатмените на главниот модел со абатмените од двофазна отпечаточна техника во 2 чекора, тие се пошироки во просек $81 \mu \mathrm{m}$, додека пак абатмените од двофазната отпечаточна техника во 1 чекор се пошироки во дијаметар во просек $281 \mu \mathrm{m}$. Анализата на резултатите добиени со примена на различните отпечаточни техники за дијаметарот на абатмените, потврдуваат дека двофазната отпечаточна техника во 2 чекора е димензионално постабилна и попрецизна во однос на двофазната отпечаточна техника во 1 чекор. Добиените резултати укажуваат дека димензионална стабилност и прецизност на отпечаточните материјали зависи од изборот на соодветна отпечаточна техника и нивно правилно изведување се со цел на добивање квалитетен отпечаток кој ќе биде основа за квалитетна фикснопротетичка изработка. 
